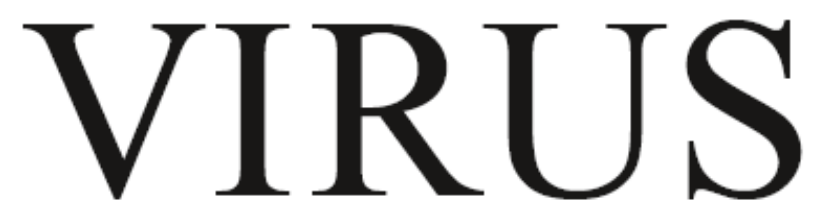

Beiträge zur Sozialgeschichte der Medizin

Band 7

Herausgegeben von

Sonia Horn, Marcel Chahrour und Carlos Watzka

für den Verein für Sozialgeschichte der Medizin

Wien: Verlagshaus der Ärzte, 2008

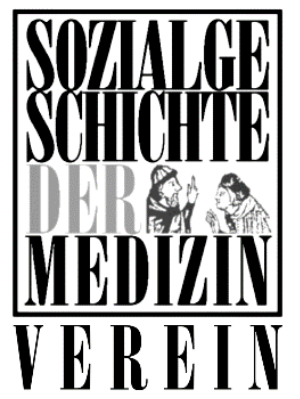


CHRISTIAN CARLETTI

\section{INSTRUMENT MAKERS AND THE DEVELOPMENT OF MEDICAL ELECTRICITY IN VIENNA DURING THE SECOND HALF OF THE NINETEENTH CENTURY}

\section{Aim of the project}

The question I am focusing on is the close interaction between physiology and studies on the physics of electricity as well as on the collaborations between the instrument makers, who provided the equipment for teaching and research in these two areas of scientific inquiry and the inventors interested in the use of electricity for practical purposes. Much has been done on this subject with regard to the late eighteenth and early nineteenth centuries. ${ }^{1}$

In that period, when the design and construction of electric machinery and apparatus had not yet specialized, the instrument makers represented the "trait d'union" in a wide network of natural philosophers and "users" of electricity.

It is of particular interest to explore how this sector began to specialize in the second half of the nineteenth century and how the relations between scientific, medical and manufacturing communities changed. Research in this direction has been already carried out with regard to some countries, ${ }^{2}$ but still there is much left to be investigated, for example, in the case of the Austrian Empire in general, and in particular Vienna. As far as we know today, there was not a long established tradition of research on electricity in this area. The extraordinary international success of telegraphy obviously enhanced the attention for the commercial applications of electricity for the time and at the same time the interest in its medical applications increased. Starting from the diffusion of telegraphy in Austria, the aim of my project is to survey the sources for a detailed study of the developments in construction of both medical and physical use of electricity as well as electrical machinery.

\section{Primary sources}

Periodicals, textbooks written for high school students, specialized and popular journals offering to their readers general information on the most recent discoveries on electric therapies, and also the clinical cases described in local newspapers allow to identify the main areas of research and of application, the main "actors" and their inter-connections, and the main sites and location in which medical electricity was practiced. However, the source of documentation I am exploring concerns more specifically the activity of the instruments makers and
1 Christine BLONDEL, Françoise PAROT, Anthony TURNER, Mary WILLIAMS (Eds.), Studies in the History of Scientific Instruments (London 1989); Iwan Rhys MORUS, Frankenstein's Children: Electricity, Exhibition, and Experiment in EarlyNineteenth-Century London (Princeton 1998).

2 Andrew CUNNINGHAM, Perry WILLIAMS, The Laboratory Revolution in Medicine (Cambridge 1992); Robert FOX, Anna GUAGNINI, Laboratories, Workshops and Sites (Berkeley 1999). 
3 Christian CARLETTI, Consuetudine e privilegi. Il governo dell'innovazione nel Regno Lombardo-Veneto. In: Paola GOVONI (Ed.), Storia, scienza e società. Ricerche sulla scienza in Italia in età moderna e contemporanea (Bologna 2007) 105-141.

4 Cristoph HOFFMAN, Helmholtz's Apparatuses. Telegraphy as Working model of Nerve Physiology. In: Philosophia Scientiae 7 (2003) 129-149.

5 Jeffrey KIEVE, The Electric Telegraph. A Social and Economic History (New York 1973) 22. For a history of telegraphy in Austria, see Franz PICHLER, Elektrisches Schreiben in die Ferne: die Telegraphie in Österreich, technische Entwicklung 1846 - 1906 (= Schriftenreihe Geschichte der Naturwissenschaften und der Technik 12, Linz 2007). manufacturers: Printed catalogues in particular, because of their farreaching circulation both in Europe and in the United States, provided an exceedingly useful depository of information. Not only they offer indications about the commercial value of the instruments and other important information about the activity of the instruments makers; further they were a most effective form of knowledge and competence transfer and a valuable source for a detailed identification and analysis of the innovative steps in the design and construction of apparatus.

However, the most important source which I intend to explore are patents. The patent system adopted by the Austrian government was regulated by three main decrees issued in 1820, 1832 and 1852 and valid in all the provinces of the Austrian Empire. ${ }^{3}$ Starting from the second half of the nineteenth century scientists and instrument makers became increasingly aware of the commercial value of their inventions. This led them to seek more and more often a formal recognition for such inventions so as to benefit from the sale of the instruments, machines and processes based on them. A survey of patents will provide a valuable insight, both at quantitative and qualitative level, in the development of a market for scientific instruments in general, and in particular electrical apparatus for medical use. The list of patents (issued and/or withdrawn) was periodically published in the gazettes of the main towns of the Empire. This makes it quite easy to identify the origin of the inventors and the typology of their patented apparatus, as it can be ascertained by the titled deposited for the patent. However, a qualitative analysis can only be carried out on the basis of the full description given in the specification.

\section{"Privilegien" and instrument makers}

Telegraphy, as I have already mentioned, represents a paradigmatic case for the development of the science of electricity in the $19^{\text {th }} \mathrm{C}$. At least till the end of the 1880 s this new technology, which radically transformed quickness and ways of communication, spread and had a social impact higher than any other electrical device. Its influence in the scientific field is clearly visible if we think, for example, that Hermann von Helmoltz described nerves comparing them to the wires of telegraphic lines. ${ }^{4}$ The most interesting aspect, however, is that the development of telegraphy not only stimulated improvements in the field of theories, but also increased business ventures, capital investments and entrepreneurship. For this reason, the growing interest in telegraphy in a particular region is a good instrument to evaluate how strong the deal between science and technology of electricity and between science and commercial interests was.

In the Austrian Empire the telegraph has been adopted quite late: Te first line was installed in 1846 between Vienna and Brno, nine years after William F. Cooke e Charles Wheatstone obtained the first patent on telegraphy in England. ${ }^{5}$ Until then commercial interests coming from 
this new technology did not generate much attention in Austria, however starting from the 1850 s requests for new telegraphic apparatus or innovation concerning the telegraphic system increased quickly.

From 1853 Julius Wilhelm Gintl, physicist and director of the Austrian telegraphic lines, had been working on a new telegraphic system for transmitting simultaneously two messages on a single wire, in opposite directions. This new systhem, later defined "duplex" and widely adopted in United States, was for the first time experimented on the line between Vienna and Linz. In 1855. As soon as he had obtained his first results, Gintl requested and obtained his first "privilege". ${ }^{6}$

In the same period also Siegfried Marcus, who moved in Vienna in 1852, opened a mechanic's shop where he sold physical and mechanical apparatus. Marcus is well known because he invented the carburettor, patented in 1865 , and an internal combustion engine applied to a car. Marcus collaborated with Werner Siemens and was interested in electrical machineries as well and here I want to mention that he obtained the first privilege in 1858 for a new electromagnetic inductor and that the electrical telegraph he invented got a privilege in $1861 .^{7}$

Around the mid-nineteenth century there were also many professional scientific instrument makers in Vienna became more and more interested in the privileges system. Karl Winter, for example, invented some electrostatic apparatuses for experimental and medical use in the beginning of 1850s and Johann Michael Eckling obtained his first privilege in the field of electricity in 1855, when he invented an electrogalvanic inductor. ${ }^{8}$

Technical abilities in Vienna, however, did not concern only electrical or mechanical apparatuses. Heinrich Kappeller started working on barometry at the beginning of the 1860s and around the end of the century he directed an instruments' shop where he sold physical and optical apparatus. ${ }^{9}$ Josef Leiter, mechanic and instrument maker, built mechanical and surgical instruments. He started working around the end of 1840s and obtained his first privilege in 1856. Georg Simon Plössl, who owned an optical laboratory in Vienna from 1823, is well known for the microscopes he built and sold to many scientists in Europe. Peter Wilhelm Friedrich von Voigtländer, son of Johann Friedrich, was the last heir of a flourish company. During the 1850s Peter Wilhelm Friedrich von Voigtländer owned two factories in Vienna where he produced mathematical, optical and mechanical instruments. Later he worked in particular on photography. Voigtländer and Plössl were developing the field on optical studies opened by Joseph von Fraunhofer. ${ }^{10}$

\section{Circulation of knowledge in the Vienna Medical School}

In the first stage of my research I am going to analyze the intellectual climate and the economic context which encouraged instrument makers and inventors to become more and more interested in the possibility of obtaining privileges. In the second stage I am going to focus my
6 Österreichisches Patentamt, Julius Wilhelm GINTL, Privilegium n. 1858/000130, 26/09/1855, Mehrere Depechen telegraphieren.

7 Österreichisches Patentamt, Siegfried MARCUS, Privilegium n. 1861/000292, 07/12/1858, Erfindung eines magnetoelektrischen Induktors; Privilegium n. 1861/000401, 16/01/1860, Telegraphenapparat.

8 Österreichisches Patentamt, Johann Michael Eckling, Privilegium n. 1855/000069, 06/03/1854, Elektrogalvanischer Induktionsapparat.

9 Heinrich KAPPELLER, Preis Verzeichnis und Abbildungen. Physikalischer und Meteorologischer Instrumente (Wien 1895).

10 Myles W. JACKSON, From Theodolite to Spectral Apparatus: Joseph von Fraunhofer and the Invention of a German Optical Research Technology. In: Bernward JOERGES, Terry SHINN (Eds.), Instrumentation between Science, State and Industry (Dordrecht 2001) 17-28. 
attention on physicists and physicians and, in particular, I would like to study their interaction with instrument makers working in Vienna or abroad. Moreover, my aim is to analyze the impact of electricity on in the field of medicine.

Starting from this perspective, the constitution of laboratories should be kept in consideration, the use of instruments and the theoretical ambitions of protagonists of the "Vienna Medical School of the $19^{\text {th }}$ C.". The leading role of Carl von Rokitansky in the field of anatomical studies, his interest inr chemistry and the introduction of the microscope, as well as the studies of Josef Skoda in the field of clinical pathology have been already explored. With regard to physiology, on which I am going to focus my attention, is tightly correlated to the development of the physics of electricity. Further, the close relation between Vienna and Berlin has to be kept in mind. Particularly interesting are physician like Ernst Brücke and Carl Ludwig. Both of them, together with Hermann von Helmholtz and Emil du Bois-Reymond, were Johannes Müller's pupils in Berlin, and in 1847 both of them (again with their colleagues Helmholtz and du Bois-Reymond) were working on a kind of manifesto in which they declared, that studies on living bodies had to switch to a new chemical and physical approach. This crucial transition meant the abandon of German Naturphilosophie and it was at the same time the beginning of a new kind of medicine, now based on laboratory studies. ${ }^{11}$

In Vienna, the physician who took the first steps in this direction was Ernst Brücke who opened a new school of physiology and a new laboratory in 1849. The laboratory which Brücke organized and directed at the "Josephsakademie" was one of the first and one of the most important in Europe and I consider it a remarkable case study. I intend to explore Brücke's "laboratory life", the activity of instrument makers engaged in his new school of physiology and the interests of Brücke's student. Moreover I want to analyze this case study also because it is in this context that enhanced also the attention for electricity and electrotherapy. The new methods experimented by Duchenne de Boulogne at Paris and Robert Remak at Berlin attracted the attention of Benedikt Schultz, Moriz Benedikt, August von Haerdtl and Friedrich Fieber. ${ }^{12}$ Fieber, in particular, played an important role and promoted the use of electricity in the filed of medicine. In 1867 he obtained the possibility to open a new department for electrotherapy and in 1869 published a Compendium der Elektrotherapie which had a wide circulation in Europe. ${ }^{13}$ With this I will show the impact of the developments in electricity and physiology and describe the role of the Vienna school of medicine in the $19^{\text {th }} \mathrm{C}$. in the European context and the transfer of knowledge.

11 William BYNUM, Science and the Practice of Medicine in the Nineteenth Century (Cambridge 1994) 98-99.

12 Erna LESKY, The Vienna Medical School of the 19th Century (Baltimore 1976) 348-349.

13 Friedrich FIEBER, Compendium der Elektrotherapie (Wien 1869).

This research project is funded by a grant of the rector of the Medical University of Vienna and will be carried out at the "Collections of the Medical University of Vienna". 